\title{
The Level of Conservatism in Accounting Policies and Its Effect on Earnings Management
}

\author{
Suzan Abed ${ }^{1}$, Jomana Al-Badainah ${ }^{2} \&$ Jamal Abu Serdaneh $^{3}$ \\ ${ }^{1}$ Applied Science University, Faculty of Economic and Administrative Science, Accounting Department, Amman, \\ Jordan \\ ${ }^{2}$ The World Islamic Science and Education University, Faculty of Business and Finance, Accounting Department, \\ Amman, Jordan \\ ${ }^{3}$ Arab Open University- Jordan Branch: Faculty of Business Studies-Business Administration Program, Amman, \\ Jordan
}

Correspondence: Suzan Abed, Applied Science University, Faculty of Economic and Administrative Science, Accounting Department, Amman 11931, P.O. Box (166), Jordan. Tel: 962-6-560-9999 Ext. 1383. E-mail: s_abed@asu.edu.jo

Received: March 13, 2012

Accepted: April 6, $2012 \quad$ Published: June 1, 2012

doi:10.5539/ijef.v4n6p78

URL: http://dx.doi.org/10.5539/ijef.v4n6p78

\begin{abstract}
This study investigates the level of conservatism in accounting policies and examines its effect on earnings management for a sample of 259 Jordanian Manufacturing companies during the period 2006-2009. The results indicate that there are differences on the level of conservatism between companies. Furthermore, the results of this study reveal that conservatism and size are negatively related to earnings management, whereas performance found to be positively related to earnings management.
\end{abstract}

Keywords: earnings management, conservatism, manufacturing companies, Jordan

\section{Introduction}

Conservatism was a controversial concept in accounting at the beginning of this century and it remains so today. Despite the criticisms leveled against it, conservatism plays an important role in the practice of accounting (Hendriksen, 1982). Descriptions of conservatism range from the extreme caution to anticipate no profits, but anticipate all losses to the more innocuous choice of the lower estimate of future cash flows when two estimates are equally likely (FASB, 1980).

Conservatism appears to have had a role in accounting-income-based management compensation. An optimal performance measure for compensation purposes reflects the effects of the manager's actions on the value of the firm in the compensation period - it is timely (Holmstrom, 1982).

Accounting conservatism is related to the agency argument for the accruals anomaly. For example, the contracting explanation of conservatism maintains that conservatism is used by shareholders, among others, to mitigate the agency problems (Kothari et al., 2008; Raith, 2009). The separation of ownership from control and its consequent agency problems give rise to demand for mechanisms by shareholders of firms to ensure that professional managers act in their (stakeholders) best interests (Fama and Jensen, 1983). Dechow and Skinner (2000) pointed out that earnings management could take place in the form of income smoothing. Using an example of a software company, they elaborate that company managers could use their reporting discretion and defer part of the recognition of sale. This deferring of sales is done in a period where the actual sales exceed the budgeted sales.

Financial reporting plays a fundamental role in this context because financial reports serve as a primary source of information for outside user in both firm valuation and in evaluating managerial performance (Parthasarathy, 2010). The vast literature on earnings management (e.i, Schipper, 1989, Burgstahler and Dichev, 1998) examined the role of financial reporting in providing managers with a natural incentive to cast their performance in an opportunistic behavior. However, to our knowledge, there is little research on the link between conservatism and earnings management, and its importance in better understanding managerial reporting behavior. The current paper concentrates on discussing and analyzing the effects of conservatism on earnings management among firms operating in Jordanian Manufacturing sector for the period from 2006-2009. 
In the recent time, the financial market in Jordan suffers from credit crisis; banks played an important role in evaluating companies' assets for lending purposes. Afterwards, it can be concluded that fair value approach might not have been sufficient to present accurate decision about the financial situation of particular company. This study helps in establishing a relationship between the role of accounting conservatism in improving efficiency of debt contracts. Literature review documented that accounting conservatism helped in improving the efficiency of the debt covenant by increasing the ability of accounting information to predict the future (Watts, 2003; Ball and Shivakumar, 2005; Ball et. al, 2008).

The remainder of this study is set out as follows: section 2 reviews previous studies and develops hypotheses based on exciting theories. Section 3 presents the research design and describes the data. Section 4 discusses the results. Section 5 provides a summary to the research findings and presents the main conclusions of the study. Moreover, contributions to the literature and suggestions for future researches are also presented.

\section{Literature Review and Hypothesis Development}

Prior accounting research has theoretically examined the relationship between earnings management and conservatism. For example Watts $(1993,2003 a)$ suggested that conservatism leads to greater reliability of accruals. Richardson et al. (2005) empirically showed that greater reliability of accruals also increased their persistence in predicting one-year-ahead earnings and returns. Ahmed et al. (2002) and Zhang (2008) indicated that conservatism is used by firms to receive lower borrowing rates in debt contracts through reducing the downside risk of creditors. Recently, Wakil (2011) showed that overall degree of conservatism incrementally increased the persistence of accruals in predicting one-period-ahead earnings. Lafond and Watts (2007) and Lafond and Roychowdhury (2008) provided evidence that lack of conservatism will likely reduce the usefulness of accounting numbers in addressing the issue of agency conflicts between managers and shareholders.

Parthasarathy (2010) examined the relationship between corporate governance and conservatism. She found that as the level of incentive alignment increases, financial statements are reported less conservatively. Accordingly, she highlighted that incentive alignment is a key concept in understanding when conservative reporting is beneficial and when it is redundant. LaFond and Watts (2008) argued that conservative financial reporting is a governance mechanism that reduces the managers' ability to manipulate performance and increases the firm's cash flows.

Kothari et al. (2008) highlighted that high accrual firms having accruals that are managed upwards, and therefore, are more transitory. Conservatism due to compensation contracts constrains management's upward bias in earnings, thereby, making accruals more persistent in predicting earnings. Ahmad et al. (2002), Zhang (2007) and Lobo et al. (2008) reported negative association between conservatism and earnings management. Hence, based on agency theory, it can be hypothesized that:

H: Ceteris paribus, there is a negative relationship between the level of discretionary accruals and the extent of accounting conservatism

Beatty et al. (2007) employed four different measures of conservatism namely the market-to-book ratio, the Basu coefficient, non-operating accruals and the skewness of earnings distribution to create a combined measure of conservatism. Consistent with Beatty et al. (2007) only two proxies will be employed in the current research to measure the level of conservatism, namely, market to book value and non-operating accruals.

The current study employs alternative control variables to examine the relation between conservatism and earnings management; namely, company size, financial leverage, audit size and performance.

\section{Research Design}

The study examines all manufacturing companies listed on the Amman Stock Exchange (ASE) for the period from 2006 to 2009. The total number of manufacturing companies listed in ASE in 2009 is 89 company. 15 companies are excluded from the study due to insufficient financial data. In addition, 7 of which are deleted due to merger and acquisition activities. Furthermore, 9 outlier observations are deleted before that analysis has been conducted. Consequently, the final sample consists of 259 firm-observations for the companies listed on the ASE for the period 2006-2009.

\subsection{Variables of the Study}

\subsubsection{Dependent Variable: Earnings Management}

In this study, accounting accruals approach is used to measure earnings management. In employing the modified Jones' (1991) model, working capital accrual are decomposed into non-discretionary and discretionary accrual. The majority of previous studies have used abnormal accruals (or discretionary accruals, DA) as a proxy for earnings management. Discretionary accruals are used to demonstrate that managers transfer their accounting earnings from one period to 
another. That is, discretionary accruals are open to managers' manipulation. Additionally, non-discretionary accruals reflect the non-manipulated accounting accruals items because they are out of managers' control.

The current study uses the cross-sectional modified version of Jones' model (Jones, 1991; and Dechow et al., 1995) to obtain a proxy for discretionary accruals. Dechow et al. (1995) and Guay et al. (1996) argued that the modified Jones model is the most powerful model for estimating discretionary accruals among the existing models. Based on the above argument, DA can be measured as follows:

Total accruals as previously mentioned is the difference between earnings and cash flows from operating activities

$$
\text { TACCit }=\text { NIit- OCFit }
$$

Where:

TACCit $=$ total accruals for company $i$ in year $t$

NIit $=$ net income before extraordinary items for company $i$ in year $t$

OCFit $=$ operating cash flows for company $i$ in year $t$

Equation 2 below is estimated for each firm and fiscal year combination

$$
\text { TACCit } / \text { Ait-1 }=\alpha 1(1 / \text { Ait-1 })+\alpha 2(\triangle R E V i t-\triangle R E C i t) / \text { Ait }-1+\alpha 3(\text { PPEit } / \text { Ait-1 })+e
$$

TACCit $=$ total accruals for company $i$ in year $t$

Ait-1 = Lagged total asset for company $i$

$\triangle \mathrm{REVit}=$ change in operating revenues for company $i$ in year $t$

$\triangle$ RECit $=$ change in net receivables for for company $i$ in year $t$

PPEit $=$ gross property, plant and equipment for company $i$ in year $t$

$\alpha 1-\alpha 3=$ regression parameters

e $\quad=$ error term

Non-discretionary accruals are measured for each year and fiscal year combination using the equation 3 as follows:

$$
\text { NDTACCit/Ait-1 }=\hat{a} 1(1 / \text { Ait-1) }+\hat{a} 2(\triangle R E V i t-\triangle R E C i t)+\hat{a} 3 \text { PPEit }+e
$$

NDTACCit $=$ non-discretionary accruals for company $i$ in year $t$

Ait-1 $=$ Lagged total asset for company $i$

$\triangle$ REVit $=$ change in operating revenues for company $i$ in year $t$

$\triangle$ RECit $=$ change in net receivables for company $i$ in year $t$

PPEit $\quad=$ gross property, plant and equipment for company $i$ in year $t$

â1- â3 = regression parameters

The Difference between total accruals and the non-discretionary components of accruals is considered as discretionary accruals (DACC) as stated in equation 4

$$
\text { DACCit }=\text { TACCit }- \text { NDACCit }
$$

DACCit $=$ discretionary accruals for company $i$ in year $t$

TACCit $=$ total accruals for company $i$ in year $t$

NDTACCit $=$ non-discretionary accruals for company $i$ in year $t$

\subsubsection{Independent Variable}

This subsection presents the independent variable and their employed proxies

\subsubsection{Expantory Variable-Conservatism}

Previous studies on earning management have employed alternative proxies for conservatism. For example, Basu's 1997 model which based on that companies announce bad news before good news, because it is expected that earnings will be more related to stock trading through the period of bad news than good one (Basu, 1997). This means that conservatism does not allow simultaneous admissions of economic events when reporting earnings. Furthermore, previous studies used book to market value as proxy for conservatism (i.e., Ahmad et al., 2002; Zhang, 2007; Lobo et al., 2008). They found that conservatism is negatively related to discretionary accruals. This is in line 
with expectations that firms with higher incentive alignment are better performing and therefore would likely have relatively lower book-to-market ratio. Jain \& Rezaee, (2004) noted that reducing the ratio of book value to market value to less than one refers to a reasonable level of accounting conservatism.

\subsubsection{Control Variables}

Company Size

Previous studies indicated negative relation between company size and earnings management (Klein 2002; Xie et al., 2003; Abdul Rahman and Ali, 2006). This support the idea that smaller companies are subject to less control from authority and therefore, managers are more likely engage in earnings management activities. In contrast, Moses (1987) argued that earnings management activities increase as the size of company increase.

\section{Performance}

Prior research documents that discretionary accrual estimates are correlated with firm performance (Kothari et al., 2005). In the same manner, Bartov et al. (2000) reported that firms experiencing low firm performance have more incentive to engage in earnings management activity. This is because, lower firm performance means higher bankruptcy risk, which in turn will lead to litigation risks. Chen et al. (2006) showed that lower profitability firms have higher behavior of earnings management.

\section{Financial Leverage}

Levered companies are less able to practice earnings management because they are under close scrutiny of lenders. Debt covenant violation arguments predict positive association between earning management and financial leverage. Bartov et al. (2000) showed that leverage is positively related to earnings management activities. In contrast, Park and Shin (2003) found that financial leverage is negative and significant related to earnings management. Hamdan et al. (2011) concluded that low-debt companies in Jordan were more conservative.

Audit Size

Several studies have examined whether or not big audit firms, have better financial reporting (Francis et al. 1999; Defond et al., 2002; Krishnan, 2003; Blokdijk et al., 2006). Chung et al. (2003) argued that, to reduce litigation risk, auditors prefer their clients to make conservative accounting choices rather than non-conservative choices. Francis et al. (1999) reported that the level of discretionary accruals is significantly lower for Big 6 clients than for non-Big 6 clients. Francis and Krishnan (1999) stated that income increasing accruals are somewhat more likely to result in reporting conservatism than income decreasing accruals, and that only the Big 6 group of auditors show evidence of reporting conservatism.

Table 1 exhibits the independent variables and their proxies employed in this research.

Table 1. Independent Variables and their Measurements

\begin{tabular}{|l|l|l|}
\hline Independent Variables & Code & Proxies \\
\hline Conservatism-Book to market value & B/MV & $\begin{array}{l}\text { Firm } i \text { 's equity capital and reserves at the end of } t \text { to market } \\
\text { value at the end of } t .\end{array}$ \\
\hline Conservatism- Discretionary accruals & TACC & $\begin{array}{l}\text { Firm } i \text { 's net income from continued operation minus } \\
\text { operating cash flow }\end{array}$ \\
\hline Control Variables & SIZE & Firm $i$ 's natural logarithm of total asset \\
\hline Company size & ROE & $\begin{array}{l}\text { Firm } i \text { 's published after tax profit at the end of } t \text { divided by } \\
\text { total equity at the end of } t\end{array}$ \\
\hline Performance & Leverage & Firm $i$ 's total debt to total asset at the end of $t$ \\
\hline Leverage & Big4 & $\begin{array}{l}\text { The audit variable measured using a dichotomous variable } \\
\text { equal to } 1 \text { if the firm } i \text { is audited by the big } 4 \text { audit firms, } \\
\text { and } 0 \text { otherwise. }\end{array}$ \\
\hline Audit size &
\end{tabular}

\subsection{Regression Model}

In order to test the study hypotheses, OLS regression analysis is employed

$$
\mathrm{DACC}=\beta 0+\beta 1 \mathrm{~B} / \mathrm{MV}+\beta 2 \mathrm{Size}+\beta 3 \mathrm{ROE}+\beta 4 \mathrm{Big} 4+e
$$


Where: DACC $=$ earnings management; $\beta=$ the regression coefficient, $\mathrm{i}=0,1 \ldots 4 ; \mathrm{B} / \mathrm{MV}=$ conservatism; Size, company size; $\mathrm{ROE}=$ performance; $\mathrm{Big} 4$ = audit size; $\mathrm{e}=$ error term.

\section{Results}

\subsection{Descriptive Results}

The descriptive analysis for dependent and independent variables of the study are presented in Table 2 . As presented in Table 2, the magnitude of absolute value of earnings management in the sample has a small mean 0.133 with standard deviation of 0.197 and the range is from a minimum of 0.0001 to a maximum of 2.158 . This indicates that the deviation between companies is quite small. Additionally, this Table exhibits the descriptive analysis for the independent variables used in analysis. The results show that conservatism variable has on average .8237 with a standard deviation of 0.48 and the range is from a minimum of -0.07 to a maximum of 3.24 . This indicates that there is a variation between companies in applying conservatism policies.

Table 2. Descriptive Analysis for Earnings Management-Pooled Data

\begin{tabular}{lllll}
\hline Variables & Mean & Std. Deviation & Minimum & Maximum \\
\hline EM & 0.133 & 0.197 & 0.0001 & 2.158 \\
B/MV & .8327 & .48399 & -.07 & 3.24 \\
TACC & 0.1112 & 0.13412 & -0.37 & 0.65 \\
SIZE & 9.0190 & 2.13355 & .00 & 14.00 \\
ROE & 1.2844 & 44.22694 & -145.04 & 536.63 \\
Leverage & .4126 & .64615 & .00 & 6.71 \\
AUDIT SIZE & .92 & .265 & 0 & 1 \\
\hline
\end{tabular}

Table 3 reports the frequency distribution of conservative companies versus npnconservative companies; the result presents a frequency of 187 conservative companies (72.2\%) versus 72 nonconservative companies (27.8\%). This indicates that companies use conservatism in its accounting policies. This result is consistent with (Ahmad et al., 2002; Penman and Zhang, 2002; Mensah, et al., 2004; Zhan, 2007).

Table 3. Conservative Vs Nonconservative Companies

\begin{tabular}{lll}
\hline Classification & Number of Companies & Percentage of Companies \\
\hline Conservative Companies & 187 & $72.2 \%$ \\
Nonconservative Companies & 72 & $27.8 \%$ \\
\hline
\end{tabular}

Furthermore, Table 4 reports the results of one sample $t$-test, the result indicates that $(t=25.446, \quad s i g=.000)$ which indicates that there is significant differences between conservative and nonconservative companies.

Table 4. The Result of One Sample t-test

\begin{tabular}{lllll}
\hline Mean & S.D & t-value & Df & sig \\
\hline .8355 & .48258 & 25.446 & 215 & $.000^{* * *}$ \\
\hline *** Significant at the $1 \%$ level & &
\end{tabular}

\subsection{Regression Results}

In order to test whether earnings management among manufacturing companies is significantly associated with conservatism policies, OLS regression analysis is performed. OLS regression assumptions are checked before performing the analysis in order to ensure that the assumptions are not violated. Table 5 presents the correlation matrix among the independent variables. The results document that there is no multicollinearity problem between independent variables, the highest correlation is between audit size and conservatism variables $(\mathrm{r}=.183)$. Furthermore, tests of normality, homoscedasticity, and linearity assumptions are checked to ensure that the assumptions are not violated. 
Table 5. Correlation Matrix among Independent Variables

\begin{tabular}{llllll}
\hline Variables & B/MV & TACC & SIZE & ROE & Leverage \\
\hline TACC & -.060 & & & \\
SIZE & .385 & & & \\
& $.121^{*}$ & .008 & & \\
ROE & .080 & 0.910 & & & \\
& $-.175^{* *}$ & .034 & .004 & .011 & .058 \\
Leverage & .011 & .623 & .958 & .868 & .401 \\
& $-.118^{*}$ & -.036 & -.075 & -.071 & .303 \\
AUUDIT SIZE & .088 & .604 & .280 & .098 & \\
& $.183^{* * *}$ & -.040 & .563 & & \\
\hline
\end{tabular}

*** Significant at the $1 \%$ level

** Significant at the $5 \%$ level

* Significant at the $10 \%$ level

Table 6 presents the results of OLS-regression analysis. This model is highly significant $(\mathrm{F}=6.055 \mathrm{P}-\mathrm{Value}=0.000)$ with an adjusted $R^{2} 9.8 \%$, which means that the combinations of the Independent variables explain around $10 \%$ of variation of dependent variables. Specifically, earnings management is found to be related to conservatism, company's size and performance.

Table 6. The Result of Multiple Regression Analysis

\begin{tabular}{lllll}
\hline Variables & Coefficients & t-statistic & P-Value & VIF \\
\hline Intercept & 0.306 & $5.872^{* * *}$ & .000 & \\
B/MV & -.025 & $-1.924^{*}$ & .087 & 1.102 \\
SIZE & -.017 & $-5.016^{* * *}$ & .000 & 1.034 \\
ROE & .000 & $-2.492^{* *}$ & .018 & 1.034 \\
Leverage & -.019 & -1.349 & .181 & 1.024 \\
Audit Size & -.014 & -.618 & .676 & 1.058 \\
Adjusted R & 0.098 & & & \\
Model F Test & $6.055 \quad$ P-value $=.000$ & & & \\
\hline
\end{tabular}

*** Significant at the $1 \%$ level

** Significant at the $5 \%$ level

* Significant at the $10 \%$ level

Specifically, For $H$ : Ceteris paribus, there is a negative relationship between the level of discretionary accruals and the extent of accounting conservatism. The results of multiple regression document negative relation between earnings management and conservatism. The results find support for $H$ and for the previous studies such as (Wakil, 2011; Lubberink and Huijgen, 2000; Lafond and Watts, 2007), but inconsistent with Penman and Zhang (2002). For control variables, the results document that company's size is significantly and negatively related to earnings management. This result is consistent with (Kamarudin et al., 2003; Naveen et al., 2008). However, performance is found to be significantly and negatively related to earnings management inconsistent with (Bartov et al., 2000; Chen et al., 2006).

The results of sensitivity analysis presented in Table 7 presents that there is negative but insignificant relation between conservatism policies measured by total accrual to net income instead of book to market value and earnings management. Additionally, the results of control variables tend not to conflict with the conclusion provided by primary analysis of the study. 
Table 7. The Result of Sensitivity Analysis

\begin{tabular}{lllll}
\hline Variables & Coefficients & t-statistic & P-Value & VIF \\
\hline Intercept & 0.299 & $5.704 * * *$ & 0.000 & \\
TACC & .000 & -.027 & .407 & 1.004 \\
SIZE & -.018 & $-4.216^{* * *}$ & .000 & 1.015 \\
ROE & .000 & $2.202^{* *}$ & .029 & 1.006 \\
Leverage & -.016 & -1.174 & .242 & 1.010 \\
Audit Size & -.022 & -.667 & .506 & 1.014 \\
Adjusted R & 0.088 & & & \\
Model F Test & $5.718 \quad$ P-value $=.000$ & & & \\
\hline
\end{tabular}

*** Significant at the $1 \%$ level

** Significant at the $5 \%$ level

* Significant at the $10 \%$ level

\section{Conclusion and Future Research}

The objective of this study was to investigate the level of conservatism in accounting policies and to examine its effect on earnings management activities for companies listed on the Amman Stock Exchange (ASE) for the period 2006-2009. The results document that there is a significant variation among companies in applying alternative levels of conservatism policies. Furthermore, the results reveal that there is negative relation between earnings management and, conservatism, company's size and performance.

The current study contributes to the literature of earnings management and conservatism. It documents evidence that conservatism policies help to constraint earnings management. However, there are several areas that are not covered by the present study but could be relevant to conservatism and earning management. One possible avenue for future research is to investigate the relationship between corporate governance mechanisms and conservatism policies and its implications for earnings management.

\section{References}

Ahmed, A. S., Billings, B. K., Morton, R. M., \& Stanford-Harris, M. (2002). The Role of Accounting Conservatism in Mitigating Bondholder-Shareholder Conflicts over Dividend Policy and in Reducing Debt Costs. The Accounting Review, 77(4), 867-890. http://dx.doi.org/10.2308/accr.2002.77.4.867

Ball, R., \& Shivakumar, L. (2005). Earnings Quality in UK Private Firms: Comparative Loss Recognition Timeliness. Journal of Accounting and Economics, 39, 83-128. http://dx.doi:10.1016/j.jacceco.2004.04.001

Ball, R., Robin, A., \& Sadka, G. (September 30, 2007). Is Financial Reporting Shaped by Equity Markets or by Debt Markets? An International Study of Timeliness and Conservatism. http://dx.doi.org/10.2139/ssrn.984299

Bartov, E., Gul, F. A., \& Tsui, J. S. L. (2000). Discretionary-Accruals Models and Audit Qualifications. Working Paper. New York University- New York.

Basu, S. (1997). The Conservatism Principle and the Asymmetric Timeliness of Earnings. Journal of Accounting and Economics, 24, 3-37.

Beatty, A., Weber, J., \& Yu, J. J. (2008). Conservatism and Debt. Journal of Accounting and Economics, 45, 154-174. http://dx.doi.org/10.1016/j.jacceco.2008.04.005

Burgstahler, D, \& Dichev, I. (1998). Incentives to Manage Earnings to Avoid Earnings Decreases and Losses: Evidence from Quarterly Earnings. Unpublished working paper. University of Washington.

Chen, G., Firth, M., Gao, D., \& Rui, O. (2006). Ownership Structure, Corporate Governance, and Fraud: Evidence from China. Journal of Corporate Finance, 12, 424-448. http://dx.doi.org/10.1016/j.jcorpfin.2005.09.002

Dechow, P. M., \& Skinner, D. J. (2000). Earnings Management: Reconciling the Views of Accounting Academics, $\begin{array}{llll}\text { Practitioners, and } \quad \text { Regulators. } & \text { 235-250. }\end{array}$ http://dx.doi.org/10.2308/acch.2000.14.2.235

Dechow, P. M., Sloan, R. G., \& Sweeney, A. P. (1995). Detecting Earnings Management. The Accounting Review, 70(2), 193-225.

Fama, E. F., \& Jensen, M. C. (1983). Separation of Ownership and Control. Journal of Law and Economics, 26(2), 301-325. http://dx.doi.org/10.1086/467037

Guay, W.R., Kothari, S. P., \& Watts, R.L. (1996). A Market-based Evaluation of Discretionary Accruals Models. Journal of Accounting Research, 34, 83-105. http://dx.doi.org/10.2307/2491427 
Hamdan, A. M., Abzakh, M. H., \& Al-Ataibi, M. H. (2011). Factors Affecting Accounting Conservatism when Preparing Corporate Financial Reports: Evidence from Jordan. International Business Research, 4(3), 145-155. http://dx. doi:10.5539/ibr.v4n3p145

Hendriksen, E. S. (1982). Accounting Theory. 4th edition. Richard D. Irwin, Homewood, IL.

Holmstrom, B. (1982). Moral Hazard in Teams. Bell Journal of Economics, 13, 324-30. http://dx.doi.org/10.2307/3003457

International Study of Timeliness and Conservatism. Review of Accounting Studies, 13, 168-205. http://dx.doi.org/10.1007/s11142-008-9069-0

Jain, P., \& Rezaee, Z. (2004). The Sarbanes-Oxley Act of 2002 and Accounting Conservatism. Working Paper Series, available at: www.ssrn.com

Jones, J. (1991). Earnings Management during Import Relief Investigations. Journal of Accounting Research, 29(2), 193-228.

Kamarudin, K., Ismail, W., \& Ibrahim, M. (2003). Market Perception of Income Smoothing Practices: Malaysian Evidence. Available Online www.hiebsiness.org.

Kothari, S. P., Leone, A., \& Wasley, C. E. (2005). Performance Matched Discretionary Accrual Measures. Journal of Accounting and Economics, 39(1), 163-97. http://dx.doi.org/10.1016/j.jacceco.2004.11.002

Kothari, S. P., Loutskina, E., \& Nikolaev, V. (2008). Agency Theory of Overvalued Equity as an Explanation for the Accrual Anomaly. Working Paper, MIT, University of Virginia, Tilburg University.

Lafond, R., \& Roychowdhury, S. (2008). Managerial Ownership and Accounting Conservatism. Journal of Accounting Research, 46, 101-135. http://dx.doi.org/10.1111/j.1475-679X.2008.00268.x

Lafond, R., \& Watts, R. L. (2007). The Information Role of Conservatism. Working Paper.

Lobo, G. J., Parthasarathy, K., \& Sivaramakrishnan, S. (2008). Growth, Managerial Reporting Behavior, and Accounting Conservatism. Working Paper.

Lubberink, M. J. P., \& Huijgen, C. (2000). A Wealth based Explanation for Earnings Conservatism. Accounting and Finance Working Paper Series, The Department of Accounting and Finance, Lancaster University.

Mensah, Y., Song X., \& Ho, S. (2004). The Effect of Conservatism on Analysts Annual Earnings Forecast Accuracy and Dispersion. The Journal of Accounting Auditing and Finance, 19(2), 159-183.

Naveen, D., Dave, D., \& Naveen, L. (2008). Do Firms Manage Earnings to Meet Dividend Thresholds?. Journal of Accounting and Economics, 45, 2-26. http://dx.doi.org/10.1016/j.jacceco.2007.11.002

Park, W. Y., \& Shin, H. H. (2003). Board Composition and Earnings Management in Canada. Journal of Corporate Finance, 185, 1-27. http://dx.doi.org/doi:10.1016/S0929-1199(03)00025-7

Parthasarathy, K. (2010). Corporate Governance, Conservatism and the Agency Problem. Unpublished PhD Thesis. University of Houston.

Penman, S., \& Zhang, X. (2002). Accounting Conservatism, the Quality of Earnings, and Stock Returns. The Accounting Review, 77(2), 237-264. http://dx.doi.org/10.2308/accr.2002.77.2.237

Richardson, S., Sloan, R., Soliman, M., \& Tuna I. (2005). Accrual Reliability, Earnings Persistence and Stock Prices. Journal of Accounting and Economics, 39, 437-485. http://dx.doi.org/10.1016/j.jacceco.2005.04.005

Schipper, K. (1989). Commentary on Earnings Management. Accounting Horizons, 3(4-5), 91-102. http://dx.doi.org/doi:10.1016/0361-3682(86)90013-9.

Wakil, G. (2011). Conservatism, Earnings Persistence, and the Accruals Anomaly. Unpublished Doctor Dissertation, Kent State University. Graduate School of Management.

Watts, R. L. (1993). A Proposal for Research on Conservatism, Financial Research and Policy. Working Paper Series, University of Rochester.

Watts, R. L. (2003). Conservatism in Accounting Part1: Explanations and Implications. Accounting Horizons. 17(3), 207-221.

Zhang, F. (2007). Accruals, Investment, Growth, and the Accrual Anomaly. The Accounting Review, 82(5), $1333-1363$.

Zhang, J. (2008). The Contracting Benefits of Accounting Conservatism to Lenders and Borrowers. Journal of Accounting and Economics, 45, 27-54. http://dx.doi.org/10.1016/j.jacceco.2007.06.002 